\title{
Ordet fanger. Retslingvistik i en dansk kontekst.
}

\section{TANYA KAROLI CHRISTENSEN}

\begin{abstract}
Denne artikel introducerer til feltet retslingvistik, eller mere specifikt til det delfelt som beskæftiger sig med analyser af sprogligt bevismateriale i kriminalsager. Kriminalretslingvistikkens historie og anvendelsesområder opridses, og der gives eksempler på danske sager hvortil sprogforskere har bidraget med ekspertudtalelser. Med udgangspunkt i en autentisk dansk trusselssag illustreres en række mulige analysegreb der kan være relevante i efterforskning og bevisførelse, men med et klart fokus på nærsproglige analyser. Hovedvægten ligger på en introduktion til den helt centrale opgavetype, ophavsanalysen (eng.: authorship analysis), som sammenligner en eller flere inkriminerende tekster med tekster der er skrevet af mistænkte i sagen. Formålet er at undersøge om der er sproglige, ortografiske og formateringsmæssige træk som går igen i begge sæt tekster, og derved kan støtte en hypotese om at de har fælles ophav.
\end{abstract}

EMNEORD: anvendt lingvistik; ophavsanalyse; profilering; kriminalret; civilret

\section{ORDET FANGER}

I slutningen af februar måned 2014 modtog et sjællandsk posthus godt 100 breve adresseret til beboere på en vej i et ghettoiseret område af byen. Ingen af brevene var forsynet med porto, men der stod skrevet i hånden på hver konvolut at "afsender betaler portoen". Alene det var nok til at stoppe forsendelserne i posten, men da man så nærmere på brevene, blev det klart at der næppe var tale om den egentlige afsender, og at samtlige breve skulle overleveres til politiet med henblik på nærmere undersøgelser. Brevene var enslydende og begyndte med 
følgende lidet charmerende udsagn (afvigelser fra dansk retstavning er bevaret, her og i de følgende eksempler):

(1) Hvorfor tager i ikke hjem til jeres hjemland og synder og bedrager der som I ALLE gør her i Danmark?

I er alle en flok dumme svin som ikke bør nasse på det Danske samfund mere!

Derudover var brevene forsynet med nogle religiøst (og æstetisk) anstødelige håndtegninger (de involverer to personer, et svin, dyresex og ordene FATHER, YOU og MOTHER placeret ved pile der peger hen på motiverne).

Disse breve indgik efterfølgende i et sagskompleks hvor en 58-årig mand stod anklaget for at have fremsendt trusler direkte eller indirekte rettet mod tre forskellige personer (de ovennævnte breve klassificeres her som indirekte da de ikke er sendt til pågældende offer selv, men udsendt i hans navn). Da byretten afsagde dom i december 2015, lagde den 'supplerende vægt' (specialanklager Søren Martin Jensen, pers. komm.) på en retslingvistisk analyse som var blevet indhentet $\mathrm{i}$ sagen, og som tillod retten at 'lægge til grund' at de $\mathrm{i}$ alt 19 trusselsbreve var skrevet af én og samme person.

Datamaterialet og analyserne af det giver mulighed for at illustrere flere aspekter af hvordan sprogvidenskaben kan anvendes i kriminalsager, og jeg vil derfor vende tilbage til det senere i denne artikel. Først vil jeg dog placere sådanne kriminaltekniske analyser som en del af det større retslingvistiske felt ved at betragte det som et tilfælde af anvendt lingvistik.

Dernæst opridser jeg (kriminal)retslingvistikkens relativt korte historie, og supplerer med et overblik over de forskelligartede sager der har været på dansk grund. Med udgangspunkt i ovennævnte trusselssag præsenterer jeg nogle mulige anvendelser af lingvistikken til efterforskning og bevisførelse, med fokus på ophavsanalysen som den væsentligste og mest udbredte. 


\section{RETSLINGVISTIK SOM ANVENDT DISCIPLIN}

Retslingvistikken er et meget bredt felt som i princippet dxkker alle tilfælde hvor sprog og lov mødes. Det gælder alt fra studier af genren lovsprog over bestræbelsen på at gøre juridisk kommunikation lettere forståelig til deskriptive undersøgelser af sproglig interaktion i politiafhøringer og retssager. Og så gælder det den noget nyere, anvendte tilgang hvor sprogligt bevismateriale i kriminal- og civilsager underkastes lingvistiske analyser.

Både for dansk og engelsk diskuteres det til stadighed hvilken betegnelse der er den mest dækkende for såvel det samlede felt som for det man foretager sig inden for den anvendte del. På engelsk er termen forensic linguistics blevet brugt om begge dele gennem mange år, men det er blevet mødt med en del kritik. Kritikken går på at begrebet forensic $\mathrm{i}$ andre sammenhænge henviser til kriminalteknik og derfor ikke indfanger bredden i det overordnede felt. Mange er derfor gået over til at bruge Language and the Law som overbegreb for de mange deldiscipliner i feltet og reservere termen forensic til analyser af sprogligt bevismateriale (jf. det navneskifte som tidsskriftet Forensic Linguistics undergik i 2003 så det nu hedder International Journal of Speech, Language and the Law. Ikke desto mindre bruges også termen forensic linguistics jævnligt som overbegreb, fordi den tydeligvis vækker genklang hos folk, og nu er ganske veletableret $\mathrm{i}$ offentligheden (jf. The International Association of Forensic Linguists (http://iafl.org/) og undervisningsbøger som Olsson \& Luchjenbroers 2014 og Coulthard, Johnson \& Writght 2017).

I en dansk kontekst er retslingvistik på én gang det mest anvendelige overbegreb for det brede felt $\mathrm{g} g$ for den smallere, kriminaltekniske del heraf. Den referentielle bredde skyldes at ordet ret både kan referere til lovgivning og til domstole, og hverken udskiller det kriminal- eller det civilretlige felt. Og herhjemme har betegnelsen været brugt i denne brede betydning i længere tid, jf. Retslingvistisk Netværk (RELINE): http://jura.ku.dk/reline/dansk. Årsagen til at betegnelsen samtidig er den mest naturlige for den kriminaltekniske del, er at vi i Danmark har tradition for at omtale netop kriminaltekniske analyser med forleddet rets-; fx foretages DNA-analyser af blodprøver på Retsmedicinsk Institut: http://retsmedicin.ku.dk. 
Det er derfor særlig vigtigt inden for retslingvistikken at man præciserer hvilken del af feltet man beskæftiger sig med. I forlængelse heraf vil jeg understrege at den følgende oversigt over retslingvistikkens historie handler om det delfelt der har at gøre med sprogligt bevismateriale. Som afsnittets titel antyder, handler det i denne artikel kun om kriminalretlige sager, selvom jeg er enig med bl.a. professor Roger Shuy i at anvendelsesområdet også omfatter civilret (for mere om civilretlige sager kan jeg henvise til Shuy 2008 og på dansk grund til Schack 2008 og Jarvad 2014; se også fodnote 2). Ligeledes kommer jeg kun sporadisk ind på fonetiske analyser, som ligger uden for mit ekspertområde. Men det skal bemærkes at rets- eller kriminalfonetikken faktisk er ganske veletableret over det meste af verden, hvilket bevidnes af at den internationale organisation af retsfonetikere, IAFPA, har eksisteret siden 1991 med årlige konferencer og egne etiske retningslinjer (http:/ / www.iafpa.net).

\section{3 (KRIMINAL)RETSLINGVISTIKKENS HISTORIE OG ANVENDELSESOMRÅDER}

Den nu pensionerede, svenske professor i lingvistik Jan Svartvik er anerkendt som den mand der opfandt udtrykket forensic linguistics om sin analyse af The Evans Statements (Svartvik 1968). Timothy John Evans blev i 1950 dømt til døden for mordet på sin hustru og lille datter. En afgørende del af bevismaterialet bestod i Evans' nedskrevne tilståelse. Mange år senere kunne Svartvik så sandsynliggøre at Evans næppe selv havde forfattet de mest belastende dele af tilståelsen. Blandt de sproglige træk Svartvik fandt afvigende i disse dele af teksten, var en tendens til at placere tidsadverbialer efter subjektet frem for den mere udbredte, omvendte rækkefølge, dvs. i stedet for den mest almindelige struktur Then $I$..., indeholdt de inkriminerende afsnit strukturen $I$ then .... Dette træk er siden blevet identificeret med såkaldt 'police speak' (politijargon, kunne man kalde det), og interessant nok fundet på tværs af britisk og amerikansk engelsk (jf. Coulthard 2000 og Leonard, Ford \& Christensen 2017).

Svartviks analyse banede vej for anvendelsen af sprogvidenskabelige metoder i efterforskning og til bevisførelse på såvel anklager- som 
forsvarersiden. Den sproglige analyse af Evans' påståede tilståelse vedrørte spørgsmålet om hvem der var ophavsmand til teksten. Sådanne undersøgelser kaldes på engelsk authorship analysis, og har været kendt i litterære sammenhænge helt siden Antikken (Love 2002: 15), mens mere systematiske, som regel kvantitative, metoder kendes i hvert fald fra midten af 1800-tallet (Holmes 1998).

I en dansk kontekst hører Brøndum-Nielsens disputats Sproglig forfatterbestemmelse (1914) til de tidligste der gør brug af en systematisk, sproglig analyse til at afklare om der er samme eller forskellige forfattere eller oversættere bag en eller flere tekster:

Hensigten med nærværende studier er ad sproglig vej at forsøge en forfatterbestemmelse m.h.t. to sprogmindesmærker fra det 16. årh.s. begyndelse: Christiern IIs Ny Testamente 1524 (»Hans Mikkelsens Ny Testamente«) og De tre ældste danske Skuespil (»Christiern Hansen’s Komedier«). (Brøndum-Nielsen 1914: i)

Brøndum-Nielsen konkluderer at en undersøgelse der baseres på en registrering af ortografi, byd- og böjningsformer giver det sikreste og mest objektive resultat, men at den med fordel kan suppleres af en mere stilistisk analyse der fokuserer på ordvalg og 'forfattervaner' (1914: 136).

I en retslingvistisk sammenhæng vil jeg foreslå betegnelsen ophavsanalyse i stedet for forfatterbestemmelse. Årsagen er dels at det jævnligt er et spørgsmål om to eller flere tekster har samme ophav (forstået som samme skribent), dels at det $i$ en juridisk kontekst ikke er sprogforskerens opgave at udpege en bestemt person som ansvarlig for de inkriminerende tekster, men blot at analysere de sproglige overensstemmelser mellem disse tekster og tekster skrevet af en eller flere mistænkte. Jeg vender tilbage til de metodiske aspekter af ophavsanalyser i afsnit 6.1.

En anden måde at anvende lingvistiske analyser i efterforskningsarbejde er ikke lige så veletableret for skriftsprogsdata som for lydlige data. Det drejer sig om profilering af talere eller skribenter ud fra sproglige variable som er relateret til deres demografiske baggrund eller (for de lydlige data) deres fysik. Hvis man har lydoptagelser af en ukendt person, kan en fonetisk analyse således bidrage til at placere taleren geografisk, aldersmæssigt og kønsmæssigt, ligesom forskel- 
lige fysiske lidelser der påvirker udtalen, kan udpeges (Jessen 2008). Den geografiske placering knytter sig til dialektale træk i talestrømmen, mens alder og køn kan estimeres på baggrund af bl.a. tonehøjde (pitch) fordi stemmelæbernes vibration korrelerer med talerens højde og drøjde (Coulthard, Johnson et al. 2017: 137). I Danmark tilbydes professionelle retsfonetiske analyser af firmaet Kriminalfonetik ved Mette Hjortshøj Sørensen (http://kriminalfonetik.dk), ligesom forskere på Københavns Universitet på mere sporadisk basis er blevet bedt om erklæringer i forskellige sager (se eksempler $i$ afsnit 4).

Sproglig-demografisk profilering kan også foretages på skriftligt materiale, igen afhængigt af materialets omfang og kvalitet. I en dansk kontekst er det svært at forestille sig mange dialektale træk overført på skriftsproget, men en sproglig analyse kan bl.a. bidrage til en vurdering af skribentens uddannelsesniveau, jobtype og alder, og om skribenten har en anden sproglig baggrund end dansk. I sådanne analyser indgår både ordvalg, syntaktisk struktur, tekstopbygning, ortografi, tegnsætning og afvigende former ( $\mathrm{fx}$ stavefejl eller bevidste stilistiske virkemidler såsom markering af forlænget udtale ved en ophobning af vokaler). Det tyske forbundskriminalpoliti, Bundeskriminalamt (BKA), iværksætter rutinemæssigt sådanne sprogligt-demografiske profileringer i sager med ukendte gerningsmænd. BKA's procedurer er ISO-certificerede hvilket bl.a. indebærer en standardiseret protokol for annotering af sproglige træk (Ehrhardt 2013, 2016).

Også forsvarssiden i kriminalsager kan have stor nytte af sprogvidenskabelige analyser. Her kan det bl.a. dreje sig om at forsøge at få en sag afvist på grund af procedurefejl (fx i forhold til om en afhørt er blevet korrekt informeret om sine rettigheder; jf. Cotterill 2000 og Berk-Seligson 2002), eller om at argumentere for at sprogligt bevismateriale i sagen er misforstået eller forkert udlagt af anklagemyndigheden (fx om tiltalte faktisk accepterede bestikkelse (Shuy 2013), eller om der var tale om en reel tilståelse; jf. Coulthard, Johnson \& Wright 2017 : 167-168, 185-188; Leonard, Ford \& Christensen 2017: 892-894).

I disse år er der inden for retslingvistiske kredse stor opmærksomhed om de problemstillinger der opstår i minoritetstalendes møde med retssystemet, både i asylsager (se fx Eades 2005; Verrips 2011 og Patrick 2012) og i tolkede afhøringer hos politiet og i retten (Berk- 
Seligson 1999; Nakane 2011). Som det gælder for mange sociolingvister, har også retslingvister ofte et ideal om at hjælpe sårbare grupper og forbedre deres retstilstand, og der er blandt andet blevet udformet retningslinjer for formidling af tiltaltes rettigheder på en måde der i videst muligt omfang tager hensyn til andetsprogstalendes sproglige kompetencer ${ }^{1}$.

Som nævnt er det endnu ikke specielt udbredt at inddrage sproglig ekspertise i danske kriminal- og civilsager. I næste afsnit giver jeg en kortfattet oversigt over nogle af de danske sager der trods alt har været, inden jeg vender tilbage til den trusselssag som kort blev introduceret i starten af artiklen².

\section{DANSKE SAGER}

Det er de færreste danske sager som er afrapporteret $\mathrm{i}$ videnskabelige artikler, og det er derfor umuligt at give en fuldstændig oversigt over sager som danske sprogforskere har været involveret $i$, ligesom flere af sagerne kun kan gengives løseligt. Den første sag jeg nævner herunder, er undtagelsen der bekræfter reglen idet den diskuteres i en NyS-artikel fra 1973 i et bind under temaet Sproghandlinger.

\subsection{Kriminelle sproghandlinger}

Denne tidligste retslingvistiske sag på dansk grund er især interessant fordi den hører til de relativt sjældne sager hvor spørgsmålet drejer sig om hvorvidt der overhovedet blev foretaget en kriminel sproghandling. Det drejer sig om Peter Harms Larsens (1973) diskussion af hvorvidt to venstreorienterede aktivister havde "tilskyndet offentligt til forbrydelse" ved at forfatte en artikel til tidsskriftet politisk, revy $\mathrm{nr}$. 148, udgivet den 15. maj 1970. Herunder citeres centrale passager fra

1 Se retningslinjerne her: http://www.aaal.org/?page=CommunicationRights.

2 Jeg forbigår også her civilsager hvoraf de hyppigste har drejet sig enten om afklaring af kontraktformuleringer (som Dansk Sprognæwn løbende får henvendelser om, jf. Jarvad 2014) eller om varemærkesager hvor et beskyttet varemærke kan blive beskyttet mod andres brug af lignende mærker (tænk fx på sagen om Jensens Fiskehus, som blev indstævnet af Jensens Boffhus og måtte ændre navn) eller registrering af et nyt varemærke kan blive forhindret fordi det er almindeligt brugt i dansk allerede (man kan fx ikke få registreret varemærket Isvaffel om en is fordi det skal kunne anvendes om lignende produkter fra andre producenter, eller om ens egne, hjemmelavede isvafler; se også Schack 2008). 
nævnte artikel så læseren selv kan danne sig et indtryk af hvad sagen drejede sig om:

(2) Men hvad der er vigtigst er, at vi fandt ud af at der findes langt mere effektfulde metoder til at vise sin solidaritet med det andet Amerika og de kæmpende indokinesiske folk: at ødelægge de institutioner og firmaer der er inddraget i krigen på fjendens side [herefter opremses en række firmaer; TKC].

(3) Vi fandt ud af ved denne demonstration, at det ikke længere går at være forsvarsløse: Vi må kunne forsvare os mod angreb. Vi ønsker nemlig ikke krig mod politiet, vi ønsker at forsvare os mod dets brutalitet.

(4) Men den første forudsætning er at vi organiserer aktionerne for at opnå større effekt og det forudsætter at vi organiserer os. Den anden og meget vigtige forudsætning er at intensivere vor oplysningsvirksomhed for at forklare ansatte på disse virksomheder og folk i øvrigt formålet med disse aktioner.

(citeret fra Larsen 1973: 7 med mine understregninger)

I sin analyse fremdrager Larsen såvel semantiske som pragmatiske forhold. Ordet tilskynde er i sig selv tvetydigt og kan kort sagt betyde enten 'motivere til' eller 'opfordre til'. Som Larsen argumenterer for, kan det kun være den eksplicitte opfordring til forbrydelse der er strafbar i juridisk forstand, da man kan motivere folk til at gøre noget uden at man har det til hensigt (Larsen 1973: 17-18). I den pragmatiske del af analysen bygger Larsen på vellykkethedsbetingelserne for en direktiv (Searle 1969). Herunder ligger den såkaldte oprigtighedsbetingelse, som tilsiger at afsender faktisk skal ønske at modtager udfører den handling som direktiven drejer sig om (her altså at tilskynde andre til at begå en forbrydelse). Her kommer Larsen ind på en afgørende problemstilling som går igen i de fleste sager der omhandler potentielt kriminelle sproghandlinger, nemlig hvilken intention afsenderen har med sin ytring. Og her er problemet at folks bevidsthedstilstand er "utilgængelig for direkte empiriske undersøgelser: det er i virkeligheden kun afsenderen selv der endeligt kan afgøre spørgsmålet” (Larsen 1973: 19; se også Solan \& Tiersma 2010: 199-204 (om intentioner bag trusler) og Shuy 
2015: 287-88 (om adgangen til andres intentioner)). Jeg henviser i øvrigt til Larsens glimrende artikel for en mere udfoldet diskussion af sagen.

\subsection{Retsfonetiske sager}

Som antydet i afsnit 3, er retsfonetiske analyser relativt veletablerede internationalt set. Herhjemme er det også primært i sager med lydligt bevismateriale at politiet har henvendt sig til sprogforskere for ekspertudtalelser. I det følgende bygger jeg på oplysninger fra tidligere og nuværende ansatte tilknyttet Lingvistisk Laboratorium på Københavns Universitet ${ }^{3}$.

Ofte har det retslingvistiske aspekt af sagerne drejet sig om såvel det rent fonetiske (udtrykket), dvs. hvad bliver der egentlig udtalt, som det semantisk-pragmatiske (indholdet), dvs. hvad betyder det $i$ den pågaldende kontekst. For eksempel blev fonetikerne bedt om en udtalelse i sagen mod daværende Hells Angels-præsident Jørn 'Jønke' Nielsen for mordet på lederen af den rivaliserende motorcykelbande Bullshit, Henning Norbert Knudsen ('Makrellen'), tilbage i 1984. En del af bevismaterialet i sagen bestod i lydoptagelser fra Hells Angels' klubhus, og spørgsmålet var om Jønke udtalte at nogen skulle nakkes (eller om der snarere blev sagt nappes), herunder om det kunne betyde andet end 'at dræbe nogen'.

Den såkaldte Perle-sag fra 2009 udløste stor medieomtale af begge aspekter; udtrykket såvel som indholdet: Sagen omhandlede en anholdelse hvorunder en betjent blev beskyldt for at have råbt enten perker eller perle til anholdte. Politiet fastholdt selv at ytringen lød: "Kan du så fatte det, perle? Kan du fatte det?" Den efterfølgende diskussion i medierne gik dels på hvad perle måtte betyde i den pågældende sammenhæng, dels på om det rent fonetisk (auditivt eller akustisk) kunne afgøres om der blev sagt perker eller perle. Såvel retsakustiker Eddie Bøgh Brixen som nu afdøde professor Jens Normann Jørgensen vurderede at der snarest blev sagt perk. Andre politifolk udtalte sig siden om at perle er et almindeligt brugt udtryk når danske betjente vil "sætte folk på plads", mens politiledelsen klart frabad sig sådan en sprogbrug. Statsadvokatens rapport forholdt sig i sidste ende til en auditivt baseret

3 Især vil jeg takke lydingeniør Preben Dømler for en oversigt over de sager han selv har bistået i. 
analyse foretaget af firmaet DELTA, hvor seks lyttere nåede frem til at der blev sagt perlet.

Andre sager har haft mere teknisk-akustisk karakter. I en sag fra Frederikshavn i 1990'erne bestod opgaven i at rense en lydoptagelse af et alarmopkald for forstyrrende "ding"-lyde udsendt automatisk hvert tredje sekund af Alarmcentralen selv. Det pågældende alarmopkald blev foretaget af en mindreårig dreng under et voldsomt opgør mellem hans forældre hvorunder drengens mor stak faderen ihjel med en kniv. Det lykkedes lydingeniøren at rense optagelsen i en grad så de tilknyttede fonetikere kunne bestemme hvad der blev sagt. Derved slap sønnen for at vidne mod sin mor i retten.

\subsection{Ophavsanalyser}

Selv om ophavsanalyse internationalt set er den hyppigst anvendte kriminallingvistiske metode, er det endnu kun sjældent brugt herhjemme. Der har dog været $\mathrm{i}$ hvert fald tre sager af meget forskelligt tilsnit. To af dem omtaler jeg ganske kort, mens jeg vender tilbage til den tredje i flere detaljer i afsnit 6. Den første sag stammer fra 1988-91 og er højst usædvanlig idet bevismaterialet bestod af tekster dannet ud fra pædagogstøttet brug af såkaldte staveplader. Den egentlige kriminalretlige sag er kun sparsomt beskrevet i rapporten Stavepladeundersogelse. Kan staveplade anvendes som kommunikationsmiddel for egne, viljesbestemte udsagn (Københavns Kommune 1991), men den drejer sig i korte træk om at nogle pædagoger havde anmeldt forældre for seksuelle overgreb mod deres handicappede børn uden verbalt sprog. Udsagnene mod forældrene var fremkommet med håndstøttet brug af staveplade ${ }^{5}$, og myndighederne ønskede en undersøgelse af hvorvidt den konkrete brug

4 En række forskellige avisartikler repræsenterer de forskellige vinkler i sagen: http://politiken. $\mathrm{dk} /$ indland/art4782918/Demonstrant-Han-kaldte-mig-»perker«

http://politiken.dk/indland/art4783185/Politidirektør-Betjent-sagde-ikke-perker http://politiken.dk/indland/art4783289/Lydekspert-Han-siger-»perk« http://www.b.dk/danmark/politiet-faar-uventet-opbakning-i-perle-sag http://politiken.dk/indland/art4782602/Politimand-Vi-har-altid-sagt-»perle« http://jyllands-posten.dk/indland/article4145765.ece http://www.dansk-politi.dk/artikler/2009/november/da-en-perle-blev-til-perker.aspx\#. WMf6-3ckqL8

5 En staveplade er et hjælpemiddel til psykisk udviklingshæmmede eller multihandicappede som tillader dem - med støtte fra en pædagog - at pege på bogstaver og tegn på en plade og derved 'stave' til ord og sætninger. 
af staveplade kunne give juridisk holdbare udsagn. De konsulterede forskere greb spørgsmålet an ved at udføre en serie eksperimentelle test med klienter og pædagoger som ikke havde noget med kriminalsagen at gøre.

Der indgik fire forskellige delundersøgelser i rapporten, hvoraf den sproglige delundersøgelse testede om der var signifikant forskel på kommunikationshandicappedes svar når de blev støttet af to forskellige pædagoger. Pædagogernes egne svar på samme sæt af spørgsmål blev også undersøgt for at se hvor stor en indflydelse deres sproglige stil måtte have på patienternes output. Der blev analyseret for forhold som stave- og bøjningsfejl, syntaksbrud, andel af adjektiver i forhold til det samlede antal ord (som udtryk for en teksts stil og nuancerigdom; Københavns Kommune 1991: 11), og andel af subjekter i helsætningers fundamentfelt. Mens det var svært at finde klare eksempler på en individuel sproglig profil hos de undersøgte patienter, var der flere tilfælde hvor pædagogernes profil øvede signifikant indflydelse på outputtet.

Den anden sag er af nyere dato og hører til de lykkeligvis sjældne mordsager herhjemme. Den syriske kvinde Hediga Morad blev meldt savnet den 10. oktober 2015 efter dagen inden at have afleveret sine to børn hos sin eksmand, Khalil Meme. Morad boede på det tidspunkt på et krisecenter og havde tidligere anmeldt sin eksmand for at have truet hende på livet. Trods det at der ikke var fundet noget lig i sagen, dømte et enigt nævningeting i januar 2017 Khalil Meme for drabet på Hediga. Et afgørende bevis i sagen var en sms-besked sendt fra Hedigas telefon samme dag som hun blev meldt savnet. Beskeden var skrevet på arabisk, og ifølge BT’s opsummering ${ }^{6}$ indeholdt den bl.a. udsagn der kan oversættes som i (5):

(5) Det kan godt være, at det vil vare lidt længe, men du skal ikke blive bekymret for mig. Og du skal heller ikke finde mig nu. Når jeg er faldet til ro, så vil jeg ringe til dig af mig selv, og fortælle dig min skat, at jeg har savnet dig

6 http://www.bt.dk/krimi/sms-besked-faeldede-eksmand-i-drabssag-uden-lig-nu-er-dommenfaldet. 
Mellemøstekspert, lektor Helle Lykke Nielsen afgav vidneerklæring i sagen på baggrund af analyser af den påståede afskeds-sms sammenholdt med tidligere sms'er skrevet af hhv. Morad og Meme. Arabisk beskrives ofte som et diglossi-sprog med betydelige forskelle mellem moderne standardarabisk og flere forskellige dialekter, og derfor fokuserede Nielsen i sin analyse på træk der kun udviste svag standardisering, for bedre at kunne finde frem til idiosynkratiske træk hos de to skribenter. Især stavningen af visse partikler og måden de sammenskrives med andre ord på, var distribueret forskelligt i de to sæt sms'er. Sammen med øvrige indicier i sagen vurderede retten at der var ført tilstrækkeligt bevis for at Meme havde myrdet Morad, bortskaffet liget, og skrevet afskeds-sms'en fra hendes telefon.

Der findes eksempler på flere andre kriminalsager hvori danske sprogforskere har vidnet, bl.a. om samtaleanalyser af båndoptagede telefonsamtaler (Femø Nielsen, pers. komm.) og nærsproglige analyser af chatbeskeder ${ }^{7}$. I det følgende vender jeg tilbage til den sjællandske trusselssag som jeg introducerede $\mathrm{i}$ indledningen.

\section{DE 19 TRUSSELSBREVE}

I dette afsnit fremhæver jeg forskellige aspekter af de 19 trusselsbreve for at illustrere forskellige analysemetoder som jævnligt bringes $i$ anvendelse inden for retslingvistikken. Med udgangspunkt i et enkelt af trusselsbrevene giver jeg en introduktion til hvordan trusler kan betragtes som sproghandlinger, og hvordan betingede trusler kan analyseres som argumenter. Samme brev eksemplificerer hvordan en analyse af tekstens forudsætninger kan bidrage til billedet af afsender og modtager i form af de tekstlige størrelser fortæller og adressat, og antyder at en sådan analyse kan bruges direkte $\mathrm{i}$ trusselsvurderinger.

Endelig introducerer jeg til det samlede materiales beskaffenhed så det kan fungere som baggrund for udvalgte nedslag i hvilke sproglige og formateringsmæssige træk der indgik i den oprindelige ophavsanalyse af materialet.

7 http://politiken.dk/kultur/kultur_top/art5624325/Sprogforsker-vidner-for-f\%C3\%B8rstegang-i-terrorsag. 


\subsection{Truslen som sproghandling}

Som Fraser (1998) forklarer, er det relativt enkelt at definere hvad sproghandlingen 'at true' er, dvs. hvilke vellykkethedsbetingelser den har (jf. Searle 1969), men det er ganske svært at afgøre hvornår netop den sproghandling har fundet sted. Det skyldes at betingelserne opfyldes af kontekstuelle forhold som kan være svære at få adgang til, ikke mindst da de i vidt omfang hviler på afsenders opfattelse af hvad der vil kunne skade modtager. Fraser opsummerer sin definition af truslen som sproghandling på denne måde:

(6) the speaker must intend to express by way of what is said

1. the intention to personally commit an act (or to see that someone else commits the act);

2. the belief that the results of that act will affect the addressee in an unfavourable way;

3. the intention to intimidate the addressee through the awareness of the intention in 1.

(Fraser 1998: 171)

Det er en pointe hos Fraser at det er afsenders intention om at true som er bærende for at sproghandlingen har illokutionær kraft som en trussel. For så vidt som modtager forstår at hensigten var at true, er det en trussel uanset om modtager selv regner handlingens udkomme som ugunstigt eller ej: Hvis en person truer en anden med at medbringe hyacinter næste gang de ses, i den tro at modtageren er stærkt allergisk over for hyacinter, så gør det ingen forskel hvis modtageren faktisk ikke er allergisk over for disse blomster. Hvis modtageren indser at hensigten var at forårsage ubehag, er der tale om en trussel. Til gengæld hører det til sproghandlingens perlokutionære effekter om modtageren føler sig skræmt af truslen, og det er således ikke en definerende del af truslens illokutionære kraft (Fraser 1998: 162).

Et illustrativt eksempel på bredden $\mathrm{i}$ hvad der kan fungere truende og hvordan ko-teksten indvirker på fortolkningen - findes i Tekst nr. 12 (jf. Tabel 1 nedenfor og Bilag 1, hvor den er gengivet i sin helhed, dog uden modtageradresse). Teksten er skrevet med en såkaldt deko- 
rativ skrifttype (det minder lidt om en udsmykket håndskrift), og de første linjer lyder således:

(7) Hej med dig din gamle pædofile stodder!

Vi har ondt af dig da dit liv efter 1. februar vil ændre sig totalt hvis du ikke betaler hvad du skylder.

Starthilsnen er ikke i sig selv truende, men udgør til gengæld samme kontrast mellem noget imødekommende og noget frastødende som fremkaldes af skrifttypevalget i forhold til brevets overordnede budskab: Hej med dig lyder venskabeligt mens din gamle padofile stodder er både nedsættende (stodder) og injurierende (pacdofile).

Den første oversætning i perioden efter starthilsnen (jf. (7) ovenfor) er en ekspressiv sproghandling som ifølge ordvalget tilsyneladende udtrykker bekymring eller omsorg for modtageren (vi har ondt af dig), men i konteksten af starthilsnens skældsord givetvis ikke oprigtigt ment. Med reference til Grices samarbejdsprincip kan man analysere det som et åbenlyst brud på kvalitetsmaksimet, som handler om at man ikke bør sige noget der er usandt, eller som man ikke har belæg for (Grice 1975). Perioden fortsætter med en adverbiel ledsætning (da dit liv...) der angiver årsagen til at man kunne have ondt af modtageren, nemlig en forudsigelse om at hans liv vil undergå en total forandring. Man kan som læser inferere sig til at denne forandring ikke vil være til det bedre når den vil lede til at folk kan have ondt af modtageren.

Det kræver både læsning af resten af teksten og yderligere inferentielle skridt at nå frem til et bud på hvad der skulle føre til denne formentlig uønskede forandring. Ca. midt på siden står der bl.a.:

(8) du er et svin som har snydt så mange samt den kone du var gift med i 3 uger da du ikke kunne holde dine beskidte fingre fra hendes datter.

Din omverden vil få alt $\mathrm{i}$ vide om $\operatorname{dig}[\ldots]$

Man må antage at truslen i sidste ende består $\mathrm{i}$ at der vil blive fortalt om nogle moralsk forkastelige forhold som involverer modtager, og at det er disse 'afsløringer' der vil føre til at modtagers liv 'ændrer sig totalt' 
(givetvis hentydes der til mulige sociale sanktioner fra hans omgangskreds). Såfremt påstandene om modtagers handlinger er sande, kan det virke som en stærk trussel at få dem afsløret, men selv usande påstande kan naturligvis indebære en vis skade på ry og rygte.

Afsløringerne kan betragtes som en sanktion der iværksættes såfremt modtager ikke opfylder den betingelse der udtrykkes i bvis-sætningen (... hvis du ikke betaler hvad du skylder). Der er dermed tale om netop en betinget trussel, dvs. en trussel om en sanktion som kun udløses hvis modtager udfører (eller her ikke udfører) den handling som betingelsen refererer til. Det leder direkte til muligheden for at analysere denne trussel som et logisk argument.

\subsection{Den betingede trussel som argument}

Den nævnte trussel kan opstilles i form af det klassiske, syllogistiske modus tollens-argument, hvor antecedenten bare er negeret ${ }^{8}$ :
(9) $\neg \mathrm{p} \rightarrow \mathrm{q} \quad$ (Hvis ikke $\mathrm{p}$, så q) $\neg \mathrm{q} \quad$ (Ikke q) $\neg \neg \mathrm{p} \quad(=\mathrm{p})($ Derfor $\mathrm{p})$

I forsimplet form lyder argumentet fra trusselsbrevet altså:

(10) Hvis ikke betaling, så livsændring

Ikke livsændring

Derfor betaling

Pointen er at modtager (ifølge afsenders fremstilling af sagen) har mulighed for at påvirke udfaldet af den forudsagte sammenhæng: Hvis han ikke ønsker en dramatisk livsændring, kan han udføre den handling som antecedenten refererer til, og dermed (ifølge argumentets struktur) undgå de negative konsekvenser. Som andre steder i logikken er det underforstået at der er tale om en 'alt andet lige'-sammenhæng:

8 Det kan også beskrives som en gyldig udgave af det ellers fejlagtige $A d$ baculum-argument, 'argumentation med staven/køllen', der appellerer til afsenders styrke eller magt. Den gyldige udgave kan beskrives således: "Hvis du gør p, vil q ske for dig. Du ønsker ikke at q sker. Derfor må du undlade at gøre q". (se http://rationalwiki.org/wiki/Argumentum_ad_baculum). 
Naturligvis kan modtageren blive udsat for stærkt forandrede livsvilkår også selv om han betaler - det kan jo være at der sker et dødsfald $i$ hans nærmeste familie eller lignende uden at det har noget som helst med truslens bagmand at gøre.

Specifikt hvad trusler angår, er det dog mere afgørende at afsender tager ansvar for den kausale sammenhæng (konsekventen er således ikke en nodvendig følge af antecedenten). At kausaliteten påhviler afsender, nævnes ikke altid eksplicit, og heller ikke i dette tilfælde. Walton beskriver denne type trussel som fremkommet gennem implikatur, hvilket vil sige at modtager selv må slutte sig til at den indirekte sproghandling ikke er en forudsigelse, men netop en trussel (Walton 2013: 122-125).

Derudover er det klart at når man har med en afsender at gøre der i forvejen bryder med alle normer for god, ligeværdig kommunikation, kan man selvsagt ikke stole på noget aspekt af den kausale relation: Selv hvis afsender modtager den omtalte betaling, risikerer man at han enten vil kræve mere eller alligevel gennemføre den handling som konsekventen refererer til.

\subsection{Truslens fortaller og adressat}

I forhold til Frasers (1998) beskrivelse af trusler er det påfaldende hvor distanceret afsender forholder sig til den mulige sanktion. Som vist $i$ (8) ovenfor, er den klareste beskrivelse af sanktionens karakter formuleret som en passiv, nemlig fä-passiven i Din omverden vil få alt i vide om dig. Afsender gør brug af passivens indbyggede mulighed for agensstrygning som udelader reference til hvem der har ansvar for at handlingen vil ske. I dette brev nævnes det aldrig direkte at afsender vil foretage sig noget specifikt, selv om der dog et enkelt sted (noget cirkulært) anføres følgende:

(11) Vi lover dig vi overholder hvad vi har lovet dig.......?

For at få et bedre greb om tekstens billede af afsender og modtager kan man gøre brug af en stilistisk analyse. Jeg trækker her på Ole To-

9 Fortsættelsen af denne sætning er i øvrigt meningsløs givet truslens opfordring til en bestemt handling fra modtagers side (altså pengebetalingen): "og ingen eller intet kan ændre dette”. 
gebys fremstilling af tekstaspekterne fortæller og adressat i PRAXT (Togeby 1993: 743-751), men vil også ved denne analyse kun angive nedslagspunkter.

Teksten forudsætter gennemgående et kendskab til 1. afsenders identitet, 2. beløbets størrelse, 3. nogle genstande og personer som omgiver modtager. Det første ses af at afsender aldrig præsenteres som andet end et ikke nærmere specificeret 'vi', og det andet af at beløbet kun omtales med relativsætningen hvad du skylder.

Tekstens fortæller fremstår som en der har stærke følelser over for adressaten - og som tidligere nævnt tilsyneladende omsorgsfulde følelser: vi har ondt af dig, og senere: alt andet vil vare lidt synd og undholdeligt for dig. Imidlertid trækker beskrivelserne af adressaten i modsat retning: $d u$ er et svin og senere: $d u$ er en tosedreng. Denne diskrepans mellem positiv og negativ attitude er allerede omtalt, og resultatet er at fortælleren fremstår som upålidelig. I konteksten af en trussel bidrager det til at gøre budskabet skræmmende, for hvis man ikke kan stole på fortællerens hensigter, hvordan skal man så stille sig til truslen og muligheden for at afværge den?

Hvad adressaten kender til udover afsenders identitet og beløbets størrelse, kan udledes af hvordan nye diskursreferenter introduceres (Togeby 1993: 748; Heltoft \& Hansen 2011: 65-66). Substantiver i bestemt form signalerer identificerbarhed, og i en adressatanalyse indebærer det at adressaten allerede kender til disse diskursreferenter. I denne tekst er det følgende ${ }^{10}$ :

(12) dit liv; din båd; den gamle [båd]; dine beskidte fingre; hendes datter; Din omverden; de andre; dit flotte sort betalte rakekehus.

Det er trivielt at modtageren har et liv og en omverden, men fortæller og adressat deler også kendskab til nogle genstande som er eller har været i modtagers besiddelse (såvel en gammel som en ny båd, og et rækkehus). Derudover antydes en incestuøs sammenhæng mellem

10 Bemærk at jeg ikke medregner udtrykket din gamle padofile stodder til de bestemte former da der ikke er tale om det possessive pronomen, men en form for vokativ form der primært ses i skældsord, men i øvrigt ikke er særlig velbelyst i dansk. Jeg kan henvise til Julien (2016) for en generativ analyse af sådanne "vokative prædikativer". Derudover fraregnes det bestemte udtryk den kone fordi det specificeres af den efterfølgende relativsætning du var gift med $i 3$ uger. 
modtagers fingre og hans tidligere kones datter ved brugen af adjektivet beskidte. Endelig er de andre i teksten helt uspecificeret, og det må derfor være en gruppe mennesker som adressat og fortæller sammen kan afgrænse.

Der er langt færre forhold som adressaten ifølge teksten ikke kender til i forvejen ${ }^{11}$ :

(13) 3 uger; et valg

De 3 uger refererer til den periode modtageren angiveligt var gift med sin daværende kone, og nominalsyntagmet indgår i en bestemmende relativsætning der identificerer hvilken kone det drejer sig om. Derfor er det for adressaten ny information på dette sted, mens det for den egentlige modtager må være kendt information, såfremt det er sandt at han har haft et ægteskab af så kort varighed.

Det valg der introduceres (med sætningen du har fortsat et valg), må være valget $\mathrm{om}$ at betale eller ikke betale, altså den helt centrale betingelse for truslens udførelse. Det er ikke overraskende at det bliver præsenteret som ny information for adressaten.

Uden yderligere adgang til konteksten er det umuligt at vurdere hvor mange af tekstens forudsætninger den egentlige modtager deler. Hvis adressaten og modtageren i store træk falder sammen i denne henseende, vil truslen virke mere skræmmende end hvis de ikke gør. Hvis det fx er rigtigt, som det står i næstsidste afsnit, at modtager allerede har tudet, vil det være tegn på at afsender har adgang til relativt private oplysninger om ham.

Skulle der foretages en egentlig trusselsvurdering af dette brev, ville den slags informationer indgå som et væsentligt kriterium for vurderingen af truslens alvorlighedsgrad (se Simons \& Tunkel 2013 for yderligere led i trusselsvurderinger).

11 Bemærk at jeg her fraregner udtrykkene et svin og en tosedreng da de optræder som prædikativer (begge i rammen $d u$ er ...) og derfor ikke introducerer nye diskursreferenter, men blot tilskriver et karakteristikon til modtager. 


\section{OPHAVSANALYSE: TEKSTERS SPROGLIGE FORSKEL- LE OG LIGHEDER}

Truslerne i den sydsjællandske sag omtalt $i$ indledningen indgik $i$ et sagskompleks mod én formodet gerningsmand som politiet antog var ophavsmanden til alle 19 breve. Det til trods for at brevene på overfladen er temmelig uens, og som nævnt var rettet mod hele tre forskellige ofre. Forskellene på brevene strækker sig fra forskellige modtagere og forskellige afsendernavne over forskellig skrivestil til en variation af skrifttyper. Tabel 1 opgør skematisk de mange forskellige typer modtagere og afsendere samt de indledende ord af hvert brev. Af anonymiseringshensyn er navne og stednavne erstattet med en generisk reference i kapitæler (fx OfFER1). Al øvrig tekst er skrevet som i brevene, inkl. stavefejl. Med det forbehold at en del af brevene ikke er daterede, og jeg derfor har måttet forlade mig på anklageskriftets (muligvis fejlbehæftede) tidsfæstelse, er listen organiseret kronologisk med de ældste breve øverst.

Som sammenligningsmateriale i sagen indgik 12 korte sms-beskeder som tiltalte tidligere var dømt for at have forfattet og sendt til et tidligere offer som ikke er sammenfaldende med nogen af dem fra nærværende anklage. Analysen havde dermed to trin: Dels skulle de 19 nyere breve sammenlignes indbyrdes, dels skulle brevene sammenlignes med sms'erne; i begge tilfælde med det formål at undersøge om de sproglige, ortografiske og formateringsmæssige træk i teksterne kunne støtte en hypotese om at de var skrevet af samme ophavsmand. Inden for rammerne af ophavsanalyser skelner man mellem tekster af 'omstridt' eller ukendt ophav (herefter U-tekster, eller blot U) og tekster af kendt ophav (herefter K-tekster, eller blot K); de tilsvarende termer på engelsk er hhv. questioned (Q) og known (K) (McMenamin 2002: 145; Koppel, Schler \& Argamon 2009; Leonard, Ford \& Christensen 2017: 886). 
TABEL 1. TRUSSELSBREVE I SAG FRA KORSØR

\begin{tabular}{|c|c|c|c|}
\hline$\#$ & Indledning & Afsender & Modtager \\
\hline 1 & $\begin{array}{l}\text { Hvorfor tager i ikke hjem til jeres } \\
\text { hjemland... }\end{array}$ & OFFER1 & $\begin{array}{l}\text { BEBOERE PÅ LOKAL } \\
\text { VEJ }\end{array}$ \\
\hline 2 & $\begin{array}{l}\text { Dit svin til mand har gennem flere } \\
\text { år besøgt mig mange gange... }\end{array}$ & UKENDT KVINDENAVN & OFFER1'S HUSTRU \\
\hline 3 & $\begin{array}{l}\text { Du skylder penge og det haster! } \\
\text { Dette er ingen trussel - det er et } \\
\text { løfte... }\end{array}$ & $\begin{array}{l}\text { Mvh. } \\
\text { "...mere at vare end at } \\
\text { syntes...!" }\end{array}$ & OfFer 2 \\
\hline 4 & $\begin{array}{l}\text { HUSK! } \\
\text { Oplysninger og rygter om pædofili } \\
\text { (Straf. [SAGSNR]) ikke kan slettes } \\
\text { eller blive glemt!!! }\end{array}$ & INGEN AFSENDER & OFFER2 \\
\hline 5 & $\begin{array}{l}\text { København, den xx. marts } 2014 . \\
\text { Jeg er advokat i et større advokat- } \\
\text { kontor med møderet for højeste- } \\
\text { ret, og vil her advarer ... }\end{array}$ & $\begin{array}{l}\text { Med venlig hilsen } \\
\text { Københaveradvo- } \\
\text { katen }\end{array}$ & $\begin{array}{l}164 \text { PERSONER OG } \\
\text { BUTIKKER OPREMSET } \\
\text { I INDLEDN. }\end{array}$ \\
\hline 6 & $\begin{array}{l}\text { Offentlig henvendelse nr. } 1 \text { : } \\
\text { Dette sendes/afleveres mandag } \\
\text { den } 17 . \text { marts ... }\end{array}$ & INGEN AFSENDER & OFFER2 \\
\hline 7 & $\begin{array}{l}\text { Jeg er en mindre entreprænør } \\
\text { som har udført mange arbejder } \\
\text { for OFFER } 2 \text {. Jeg har givet ham en } \\
\text { rejning ... }\end{array}$ & Med hilsen fra xx & $\begin{array}{l}\text { SkAT NÆSTVED OG } \\
\text { POLITIET }\end{array}$ \\
\hline 8 & $\begin{array}{l}\text { Jeg er en mindre entreprænør } \\
\text { som har udført mange arbejder } \\
\text { for OFFER } 2 \text {. Jeg har givet ham en } \\
\text { rejning ... }\end{array}$ & Med hilsen fra $\mathrm{xx}$ & $\begin{array}{l}\text { SkAT NÆSTVED OG } \\
\text { POLITIET }\end{array}$ \\
\hline 9 & $\begin{array}{l}\text { De } 635 \text { udsendes den } 22 . \text { maj hvis } \\
\text { der ikke reageres fra din ven. ... }\end{array}$ & INGEN AFSENDER & OFFER2'S BEKENDTE \\
\hline 10 & $\begin{array}{l}\text { Kære medlemmer i JCI, Næstved } \\
\text { og } \ldots \\
\text { Jeg skriver til jer for at advare med } \\
\text { OfFER } 2 \ldots\end{array}$ & $\begin{array}{l}\text { Med de venligste } \\
\text { hilsner fra } \\
\text { OfFER2's BEKENDTE }\end{array}$ & $\begin{array}{l}635 \text { MODTAGERE } \\
\text { OPREMSET I INDLEDN. }\end{array}$ \\
\hline 11 & $\begin{array}{l}\text { Kære KVINDENAVN }{ }^{13} \\
\text { Vi talte kort sammen i dag, hvor } \\
\text { jeg lige vil beskrive hvad der vil } \\
\text { hænde dig ... }\end{array}$ & 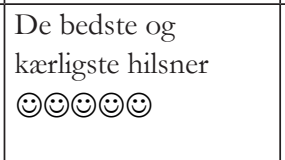 & OfFER3 \\
\hline 12 & $\begin{array}{l}\text { Hej med dig din gamle padofile stodder! } \\
\text { Vi har ondt af dig da dit liv efter } 1 . \\
\text { februar vil ... }\end{array}$ & INGEN AFSENDER & OfFER3 \\
\hline
\end{tabular}

12 NB! Dette brev er fem linjer længere end det foregående, men er indtil da ordret det samme. 13 Kvindenavnet i starthilsnen er navnet på Offer3’s båd. 


\begin{tabular}{|c|c|c|c|}
\hline 13 & $\begin{array}{l}\text { Kære OFFER3svin } \\
\text { Det er efter den første februar. } \\
\text { Vi ved du har "snakket" men det } \\
\text { hiælper dig IKKE ... }\end{array}$ & INGEN AFSENDER & OfFER3 \\
\hline 14 & $\begin{array}{l}\text { Som nævnt så skal du blot betale } \\
\text { det du skylder og min. med afdrag } \\
\text { som oplyst ... }\end{array}$ & INGEN AFSENDER & OfFER3 \\
\hline 15 & $\begin{array}{l}\text { INDBYDELSE. } \\
\text { Kære alle som bor på eller tæt på } \\
\text { [GADENAVN POSTNR BY] er alle vel- } \\
\text { komne til at komme ... }\end{array}$ & OFFER3 & Naboer til Offer 3 \\
\hline 16 & $\begin{array}{l}\text { Hej pædofile } \\
\text { Første brev var bare for sjov som } \\
\text { ingen tager sig af ... }\end{array}$ & INGEN AFSENDER & OfFER3 \\
\hline 17 & $\begin{array}{l}\text { Hej min svindlerven } \\
\text { Husk du bor i nr [husnr.] } \\
\text { Hvis dumhed blev belønnet med } \\
\text { kontanter ... }\end{array}$ & INGEN AFSENDER & OfFER3 \\
\hline 18 & $\begin{array}{l}\text { Muhammad } \\
\text { Alle i PERKERE rejs hjem og bol } \\
\text { jeres mor i røven. }\end{array}$ & OFFER3 & $\begin{array}{l}\text { Til Familien } \\
\text { Kraki el Bussemand } \\
\ldots\end{array}$ \\
\hline 19 & $\begin{array}{l}\text { Dine fine tegninger afsendes } \\
\text { mandag til vedlagte liste I første } \\
\text { omgang kun til de } 15 \text { moskeer ud } \\
\text { af } 121 \ldots\end{array}$ & $\begin{array}{l}\text { Kærlig hilsen } \\
\text { din broder. }\end{array}$ & OFFER3 \\
\hline
\end{tabular}

\subsection{Teori og metode bag ophavsanalyser}

Formålet med en ophavsanalyse er at undersøge om der er sammenfaldende træk mellem $\mathrm{U}$ og $\mathrm{K}$ som ikke blot kan tilskrives enten alment dansk, genremæssige konventioner eller særlige praksisfællesskabers rutinemæssige måde at skrive på (som fx inden for en arbejdsplads). I stilistiske ophavsanalyser leder man dels efter normafvigelser, dvs. fx stavemåder der ikke er i overensstemmelse med den relevante (dvs. sammenlignelige) norm eller konvention, dels efter stilistiske træk hvor en skribents valg af sproglige udtryk kan indikere fx formalitetsniveau, intern jargon, positiv eller negativ evaluering, m.v. ${ }^{14}$. Det svarer til en bred forståelse af hvad der udgør en sociolingvistisk variabel: To

14 Jeg forholder mig i det følgende kun sporadisk til hvad der er blevet kaldt 'stilometriske' (eng.: stylometric) ophavsanalyser. De angiver rent kvantitative mål for en teksts variation, og foretages i vore dage datalingvistisk, typisk ved hjælp af maskinlæring; jf. Koppel, Schler \& Argamon (2009). Som også anført af Solan (2013) og Coulthard, Johnson \& Wright (2017: 
eller flere udtryk der kan udfylde samme funktion i den pågældende kontekst (se fx Tagliamonte 2006).

Præmissen for at lave ophavsanalyser er at folk tillægger sig sproglige vaner som vil kunne påvises i deres skriftlige (eller mundtlige) produktion (McMenamin 2002: 27). Tim Grant beskriver de to centrale grundantagelser således:

The first assumption is that there is a sufficient degree of consistency of style within relevant texts by an individual author. The second assumption is that this consistency of style inherent in an author's writings is sufficiently distinctive to discriminate the one author from other relevant authors. (Grant 2012: 473; her citeret fra Coulthard, Johnson \& Wright 2017: 157.

Mens det er venteligt at man vil kunne finde de enkelte træk også hos andre skribenter, vil den specifikke konstellation af træk man finder hos én skribent, næppe findes hos andre - under forudsætning af at man enten har fundet frem til træk med sjælden forekomst i en sammenlignelig befolkningsgruppe eller en meget stor mængde træk (eller begge dele).

Her berører man automatisk begrebet om en idiolekt, en individspecifik sprogbrug der selvsagt vil have et meget stort overlap med sprogbrugen hos andre medlemmer af samme sprogsamfund, men som alligevel antages at være unik for den enkelte sprogbruger (Coulthard 2004). Idiolekter er relativt underudforskede, især for skriftsprog, men der findes til gengæld ganske mange datalingvistiske ophavsanalyser af store datamængder som understøtter at det er muligt at skelne skribenter på baggrund af sproglige og ortografiske træk (se eksempler i oversigtsartiklen Koppel, Schler \& Argamon 2009). Det er dog afhængigt af omfanget og kvaliteten af datamaterialet om man kan identificere en tilstrækkelig mængde overensstemmende træk mellem U og K. Her kan stilistiske analyser være heldige at identificere træk på baggrund

207), vil en kombination af stilistiske og stilometriske metoder være optimal i de fleste sager, men det er endnu yderst sjældent at det forekommer i praksis, tilsyneladende fordi der ikke eksisterer nogen kriminallingvistiske laboratorier der både har datalingvister og klassiske lingvister ansat. 
af et mindre materiale end der kræves for datalingvistiske analyser (jf. Juola 2016) ${ }^{15}$.

Der findes for nuværende ingen bredt anerkendte normer for hvor mange træk der er tilstrækkelige, eller hvordan de skal opgøres. En af de mest omtalte er sandsynlighedsforholdet (eng.: likelihood ratio) mellem trækkenes forekomst i $\mathrm{U}$ og $\mathrm{K}$ givet enten 1. den hypotese at de er skrevet af samme person, eller 2. den hypotese at de ikke er skrevet af samme person. Her forholder man frekvensen af et træk i $U$ til frekvensen af samme træk i K samt frekvensen i den generelle befolkning. Forsimplet sagt: Hvis trækket findes at være overhyppigt i både U og $\mathrm{K}$ i forhold til almindeligt dansk, er det mere sandsynligt at forfatteren til $\mathrm{K}$ også er forfatter til $\mathrm{U}$ end at en almindelig gennemsnitsdansker er det (se et eksempel på en sådan beregning i Coulthard, Johnson \& Wright 2017: 199) ${ }^{16}$.

Som det fremgår, kræver en sådan analyse imidlertid at man har adgang til et relevant referencekorpus. I Danmark er det mest anvendelige korpus KorpusDK med sine 56 mio. løbende ord (og det er særligt anvendeligt pga. de avancerede søgemuligheder der findes under Udvidet søgning og Formel søgning; jf. http://ordnet.dk/korpusdk/). Til ophavsanalytiske formål er det dog begrænset af primært at bestå af velredigerede og korrekturlæste tekster, som noveller, romaner og avisartikler. Dermed vil en stor del af de normafvigelser som også er relevante for ophavsanalyser, være renset bort allerede inden optagelse i korpusset.

Frekvensen af ortografiske afvigelser kan så i stedet estimeres ved hjælp af internetsøgninger (hvor man så dels må sikre sig at søge på alle relevante, sammenlignelige variationer, dels må notere med hvilken søgestreng og på hvilken dato søgningen er foretaget). Til gengæld kan de gængse søgemaskiner ikke bruges til at fremfinde eksempler på tegnsætningsvariation idet de som regel udelader tegnsætning fra

15 Patrick Juola rapporterer om en veludviklet software for engelsksproget data der kræver minimum 200 ord for at kunne fungere (2016: 39), men det er både afhængigt af hvilken type ophavsanalyse der skal udføres (er der fx kun én eller mange mulige skribenter der skal sammenlignes), og hvilken datalingvistisk model der anvendes (maskinlæring kræver fx stort materiale som træningssæt), jf. Koppel, Schler \& Argamon (2009).

16 En tilsvarende sammenligning med befolkningsdata beskrives for DNA-analyser her: http:// retsmedicin.ku.dk/om_instituttet/retsgenetik/Straffesager/til-journalister/. 
søgningerne, også selv om man inkluderer fx punktummer eller bindestreger i en søgestreng omkranset af anførselstegn.

Hvad stilistiske træk angår, vil der være mange som slet ikke kan opgøres statistisk fordi der ikke er et klart afgrænset, og dermed endeligt, antal varianter som man kan søge på (det ses alene på enkeltordsniveau: På hvor mange forskellige måder kan man fx omtale en person hvis man inkluderer kaldenavne, kælenavne og skældsord?).

Manglen på en bredt anerkendt metode til at opgøre ophavsanalytiske resultater er en af de alvorligste indvendinger mod ophavsanalyser som sådan, både videnskabeligt og i retten. Videnskabeligt set kan de løbende metodediskussioner (Chaski 2001; Chaski 2007; Butters 2012, Solan 2013) betragtes som et tegn på en begyndende modning af feltet, men det er naturligvis samtidig et symptom på at der er tale om et ret nyt felt. Fra det andet, mere anvendelsesorienterede, perspektiv fremfører erfarne retslingvister jæunligt at der gælder andre krav til afrapportering end dem der findes internt i det videnskabelige fagfællesskab: I sidste ende skal fundene kunne udlægges og forklares for lægmænd i form af dommer og nævninge/jury (jf. Shuy 2006 og Juola 2008: 78-80). Der findes flere eksempler fra udlandet hvor statistisk valide, retslingvistiske analyser er blevet afvist af dommeren med den begrundelse at juryen ikke vil kunne forstå indebyrden af dem (se fx Coulthard, Johnson \& Wright 2017: 201).

\subsection{Trusselsbrevene: Tematiske trak $i U$}

Når U-teksterne skal sammenlignes indbyrdes, kan man ikke undlade at bemærke et forhold der ikke kræver nogen egentlig sproglig analyse, nemlig det simple faktum at en del af brevene refererer til hinanden indbyrdes. For eksempel omtales udsendelse af en række breve som så findes andre steder i materialet, eller der refereres til samme antal modtagere af sådanne breve, eller et bestemt sagsnummer går igen.

Derudover er der visse tematiske overlap i teksterne som skyldes selve truslernes indhold. For det første fremsættes en del af truslerne som led i pengeafpresning (i syv af brevene), og verber som betale og skylde er derfor genkommende.

For det andet trues der generelt med at nogle belastende oplysninger om hver af ofrene vil blive afsløret for enten deres omgangskreds (pri- 
vat eller professionel) eller for myndighederne: I alle tre ofres tilfælde omtales forskellige (formentlig falske) pædofilisager som ofrene hver især skulle være gerningsmænd bag. Det er det mest udbredte tematiske fællestræk idet det forekommer i 12 ud af de 19 breve. For OfFEr1 og OfFer2 gælder det at de fremstilles som racister i kraft af religiøst nedgørende smædebreve udsendt i deres navn (jf. eksempel (1)), mens OFFER2 og OfFER3 begge knyttes til sager om skattesnyd.

Truslerne baserer sig således især på at der vil ske forskellige typer sanktioner ved tredjemand. Det er en mulighed der indgår som en del af Frasers (1998) definition af trusler, gengivet i afsnit 5.1 ovenfor (... that someone else commits the act, min understregning). Sanktionerne kan antages primært at have social karakter, som fx udstødelse fra forskellige fællesskaber, mens personvold aldrig omtales.

Sådanne referentielle og tematiske overlap er imidlertid ikke det primære fokus for en ophavsanalyse som bør forholde sig til alle sproglige niveauer. En typisk rapport vil indeholde afsnit der tager stilling til følgende:

- Stil (fx formalitetsgrad)

- Ordvalg og faste udtryk

- Grammatik

- Ortografi

- Tegnsætning

- Formatering ${ }^{17}$

Afhængigt af materialets karakter kan nogle af punkterne vise sig overflødige, men det bør så kommenteres i et særskilt afsnit der redegør for materialets omfang og kvalitet.

17 Formateringsmæssige træk er ikke i sig selv sproglige, men kan understøtte fortolkningen af teksten - og derudover er der stor variationsrigdom inden for formatering, hvilket er væsentligt for en identifikation af skribenters tekstuelle vaner (fx kan man fremhæve ord på flere forskellige måder: med kursiv, med fed, med understregning, med VERSALER, eller en kombination af flere af disse). 


\subsection{Trusselsbrevene: Sproglige trak i $U$}

Her gennemgår jeg i relativt kort form eksempler på de træk der viste sig overensstemmende på tværs af U-teksterne. Dernæst forklarer jeg hvordan disse træk relatererede sig til K-teksterne (de 12 truende sms'er som tiltalte tidligere var dømt for at have skrevet).

Stil. Brevene er skrevet i relativt forskelligt stilleje. Nogle er som nævnt racistiske smædebreve udsendt $i$ et af ofrenes navne, andre er mere formelt udformede anmeldelser af påståede ulovligheder, og atter andre er rettet direkte mod et af ofrene med trinvise angivelser af hvordan truslernes sanktioner vil forværres over tid. De forskellige stillejer afspejler i nogen grad de forskellige afsender-/modtagerkonstellationer som fremgår af Tabel 1. For eksempel er smædebrevet i Tekst 1, udsendt i OFFER1's navn til beboere i et socialt belastet boligområde, uformelt og præget af vurderende udsagn, skældsord og direktiver, mens fx Tekst 5, underskrevet af Kobenhaveradvokaten (sic) og stilet til en lang række virksomheder og organisationer i lokalområdet, udviser en del kancellistilstræk i ordvalg, syntaks og morfologi ${ }^{18}$.

Ordvalg. De mest interessante forekomster er dem der indgår i mindre, lukkede sæt hvor sprogbrugeren kan vælge mellem udtryk der har (omtrent) samme betydning, dvs. hvor der med andre ord er tale om variation mellem funktionelt tilsvarende størrelser. I disse tekster gælder det for det første konjunktionerne samt og og. Trusselsbrevene har i alt 18 tilfælde af samt fordelt på ti tekster, og 84 tilfælde af og fordelt på 16 tekster. Hvis man sammenligner det med fordelingen i KorpusDK, viser det sig at brevene udviser en stor overhyppighed af samt:

TABEL 2. SAMT VS. OG

\begin{tabular}{l|r|r}
\hline & $\mathbf{U}$ & KorpusDK \\
\hline samt & 18 & 18.867 \\
\hline og & 84 & 1.814 .718 \\
\hline samt-andel & $17,6 \%$ & $1,0 \%$ \\
\hline
\end{tabular}

18 Ordvalg: erbverver sig ved, reprasenterede, henvendelse; komplekse nominalsyntagmer: advokat $i$ et storre advokatkontor $i$ Kobenhavn med moderet for hojesteret, en 2 ars betinget dom; passiv: ekskluderes. 
Materialet udviser også en overhyppighed af den dialogiske partikel blot $\mathrm{i}$ forhold til partiklen bare når man sammenligner med fordelingen $\mathrm{i}$ KorpusDK:

TABEL 3. BLOT VS. BARE

\begin{tabular}{l|r|r}
\hline & $\mathbf{U}$ & KorpusDK \\
\hline blot & 8 & 19.818 \\
\hline bare & 5 & 37.310 \\
\hline blot-andel & $66,7 \%$ & $34,7 \%$ \\
\hline
\end{tabular}

Interessant nok trækker disse to overhyppige varianter i samme retning idet de er mere formelle eller gammeldags end deres ækvivalenter. Den Danske Ordbog noterer at samt især bruges i skriftsprog, mens der ikke er nogen lignende noter om blot. Til sammenligning kan det nævnes at i Sprogforandringscentrets data over moderne dansk talesprog fra 1980'erne og frem forekommer blot kun fem gange, mens bare som adverbial tæller over 14.000 forekomster.

Bemærk i denne sammenhæng at blot også forekommer i relativt uformelle tekster som Tekst 1 hvor begge dialogiske partikler findes i følgende udgangsreplik:

(14) Kom bare op til mig, så skal jeg fortælle jer, at I blot skal UD af Danmark NU - det kan ikke gå for langsomt ${ }^{19}$.

Tekst 4 er kortfattet og udformet med meget store fontstørrelser, så den ligner et opslag til ophængning. Sprogligt set er denne tekst ligeledes relativt uformel, men også her findes et tilfælde af blot.

(15) Dette VIL ske ved manglende betaling og det vil blot blive værre og værre!

......Sådan!!

19 Læseren vil notere sig sammenblandingen af de konkurrerende udtryk 'det kan ikke gå for hurtigt' og 'det kan kun gå for langsomt'. 
Bemærk her forstærkelsen ved gentagelse af samme ord (varre). Denne struktur forekommer flere gange på tværs af brevene.

Gentagelsesstrukturer. Flere af teksterne gør brug af den særlige form for forstærkelse hvor et gradsadverbium eller et adjektiv i komparativ gentages, evt. forbundet af og (i stilistikken kaldes denne gentagelsesfigur epizeuxis). Eksempler ud over det i (15) tæller (med mine understregninger):

(16) et meget meget grimt Muhamed-billede; noget rigtig rigtig skidt for dig (Tekst 11)

(17) bliver ved og ved og ved og ved til alt er betalt; langt langt billigere; mange mange flere breve; meget meget meget slemt (Tekst 14)

(18) så vil vi blive ved og ved og ved med stærkere og stærkere synspunkter (Tekst 16)

Som det fremgår, er der variation $i$ antallet af gentagelser og i brugen af paratakse med og uden konjunktion, men det at bruge forstærkende gentagelser er et genkommende mønster.

Passiv $i$ trusler. I flere af teksterne formuleres trusler med brug af passiv og agensstrygning, så man undgår eksplicitering af hvem der har ansvaret for udførelse af sanktionen, fx

(19) [der] vil blive fremsendt anmeldelse til politiet (Tekst 1)

(20) HUSK! Oplysninger og rygter omkring pædofili ... ikke kan slettes eller blive glemt!!! (Tekst 4)

(21) [så] bliver der anonymt skrevet til samtlige medlemmer i ... (6 tilfælde) (Tekst 5)

(22) Dette sendes/afleveres mandag den 17. marts, håber at hører fra dig den 14. (Tekst 6)

(23) De 635 udsendes den 22. maj hvis der ikke reageres fra din ven (Tekst 9)

(24) der vil formuleringen være helt klar og beviser vedlægges. (Tekst 16) 
Som det allerede er nævnt i afsnit 5.3 ovenfor, er passiven velegnet til netop den form for distanceret fremsættelse af en trussel.

Tegnsatning. I $17 \mathrm{ud}$ af de 19 tekster er der tilfælde af udeladt komma hvor det burde være, men ellers er kommateringen i store træk korrekt, fx forekommer der aldrig komma foran at-infinitiv. I ti af de 15 tekster der indeholder en modtageradresse, forefindes der unormeret punktum efter adresselinjer (jf. Retskrivningsordbogens $₫ 41.2 \mathrm{~b}$ ).

Formatering. Brevene bruger forskellige midler til fremhævelse af ord, men det hyppigste er brug af versaler (store bogstaver), som det allerede fremgår af eksempel (1), (14), (15) og (20). I alt gør otte af brevene brug af denne mulighed for fremhævelse i op til fire gange pr. tekst.

Der er en del andre sproglige træk som kan genfindes i to eller flere af trusselsbrevene som jeg ikke gennemgår her, men de spænder fra ironisk brugte positive adjektiver ( $\mathrm{fx}$ flotte) over afslutningsfraser ( $\mathrm{fx} S a$ dan.) til grammatiske fejltyper (fx præsens-r, atypisk præpositionsbrug og manglende sætningsopdeling).

\subsection{Sammenligning af $U$ og $K$}

I denne sag er de K-tekster der blev stillet til rådighed, kvantitativt set mindre velegnede til en sammenligning end man kunne have ønsket. De består som tidligere nævnt af 12 sms'er, og det er generelt relativt kortfattede tekster. Til gengæld er de genre- og sproghandlingsmæssigt sammenlignelige med U-teksterne idet de også har nedgørende og truende indhold.

Herunder opridses i overskriftsform de træk der er overensstemmende med U-teksterne betragtet som helhed:

- Trusselstyper:

- Sanktion ved tredjemand (rockere, indvandrere)

- Pengeafpresning

- Overlappende konstruktioner

- U: at vi ALDRIG stopper før der er betalt

- K: husk at det kan ikeke stoppe før der er betalt

- K: det kan IKKE stoppes uden betaling

- Religiøst nedgørende indhold (din lille JØDE; jodekarl; perkersvin) 
- Udeladelse af kommaer (i ti ud af 12 sms-beskeder)

- De dialogiske partikler blotvs. bare (en af hver)

- Skældsordet svin (fem forekomster)

- Forstærkelse ved ordgentagelse (mere og mere)

Om brugen af blot og bare i K må det understreges at tallene er for små til at drage nogen konklusioner idet der findes én forekomst af hver i sms-beskederne.

Som det bemærkes i ovenstående uddrag, benyttes der også versaler til fremhævelse i K. Det er imidlertid ikke fuldstændig sammenligneligt med brugen af versaler i $\mathrm{U}$ idet de formateringsmæssige variationsmuligheder ikke er de samme når der skrives på en mobiltelefon: Man kan således hverken bruge fed, kursiv eller understregning ${ }^{20}$. Derfor kan brugen af versaler i $\mathrm{K}$ alene fungere som konstatering af at ophavsmanden til disse tekster også bruger fremhævelse i sine tekster.

\subsection{Retslingvistisk, erklaring og den endelige dom}

Den retslingvistiske erklæring konkluderede at de sproglige mønstre på tværs af U-teksterne bedst kunne forklares ved at de var skrevet af samme ophavsmand, og at det samme gjaldt på tværs af U og K. En mere teknisk formulering af en sådan konklusion kunne lyde ${ }^{21}$ :

De sproglige mønstre i $\mathrm{U}$ kan bedst forklares som tilfælde af sproglige mønstre fundet i K, dvs. de er hovedsageligt overensstemmende med mønstre fundet i $\mathrm{K}$.

Denne standardformulering er imidlertid knap så velegnet $\mathrm{i}$ et tilfælde som nærværende hvor U-teksterne langt oversteg K-teksterne i omfang, og hvor det var et separat spørgsmål om de mange U-tekster

20 En alternativ måde at markere fremhævning på er ved at indsætte en understregning før og efter ordet, som i_nu_idet de fleste tekstbehandlingsprogrammer er sat op til automatisk at ændre ord indrammet af understregning til kursiv. Man kan også finde eksempler på indramning af asterisker $\left(^{*}\right)$ til samme formål, men begge er relativt sjældne i forhold til brugen af versaler til fremhævelse (Eva Skafte Jensen, pers. komm.).

21 Denne formulering er en oversættelse af en standardformulering udformet af en af de mest veletablerede retslingvistiske konsulenter på dette felt, Robert Leonard Associates; http:// www.robertleonardassociates.com/). 
var indbyrdes overensstemmende. Til gengæld har formuleringen den fordel at den holder sig fra at tilskrive teksterne til samme forfatter, og dermed overlader den slutning til domstolen.

Det er nemlig vigtigt at understrege at ophavsanalyser ikke kan udelukke at en anden person kunne have skrevet de pågældende tekster (lidt ligesom fingeraftryksanalyser og DNA-analyser kun med en vis sandsynlighed kan placere en mistænkt på gerningsstedet). Da sprogbrug principielt er uendeligt variabel, er det ikke meningsfuldt på samme måde som ved DNA-analyser at give en numerisk sandsynlighed for om en bestemt forfatter har skrevet en bestemt tekst ${ }^{22}$. En valid numerisk angivelse måtte som tidligere nævnt også forholde sig til variationen i sprogsamfundet som helhed, og det er en viden som kun er delvis tilgængelig for nuværende, især da der på dansk grund ikke er adgang til et korpus over uredigerede tekster med de normafvigelser der måtte findes i dem. Men med de forbehold som nødvendigvis må tages for datamaterialets beskaffenhed ( $\mathrm{fx}$ om det er genremæssigt sammenligneligt), vil ophavsanalysers resultater kunne tælle som indicium på om tekster har eller ikke har fælles ophav - og jo flere træk der går igen, jo stærkere et indicium vil det være.

I nærværende sag viser en aktindsigt i dombogen at ophavsanalysen blev brugt som indicium der understøttede anklagemyndighedens udlægning i fem af anklagens forhold. Det er ikke mindst i sager som denne med maskinskrevne tekster at ophavsanalyser kan udgøre et væsentligt supplement til det øvrige bevismateriale idet tiltalte uden videre kan påstå at det ikke var vedkommende selv der brugte computeren, men en anden. Hvis den retslingvistiske undersøgelse understøtter en hypotese om at $\mathrm{U}$ og $\mathrm{K}$ har fælles ophav, fremstår sådanne påstande selvsagt mindre troværdige end hvis analysen ikke viser nogen sproglige overlap.

22 Bemærk at det ser anderledes ud for de datalingvistiske analyser der groft sagt bare forholder sig til hvilket tegn der følger efter et andet i forhold til hvad man statistisk set kunne vente (og forudsigelsen vil så basere sig dels på de mulige tegn, dels på viden om det enkelte sprog eller - ved maskinlæring - hvad skribenten hidtil har gjort). Til gengæld vil den type analyser have svært ved at indfange niveauer som pragmatik og retorik som også kan være afgørende. 


\section{ANDRE ANVENDELSER AF LINGVISTIK I KRIMINAL- RETLIG SAMMENH/ENG}

Der er ganske mange andre retlige problemfelter som lingvister kan bidrage til at belyse. Som det kort er omtalt tidligere, har afhøringer allerede tiltrukket sig en del opmærksomhed. I forbindelse med politiafhøringer gælder det dels selve afhøringsteknikkerne (Gnisci \& Pontecorvo 2004; Haworth 2006; Kassin 2008), dels transformationen af mundtlig afhøring til skriftlig politirapport (Jönsson \& Linell 1991; Fisher 1993; Coulthard 2002; Farstad Eriksen 2013). Retssalsinteraktion er også et efterhånden velundersøgt emne hvor man bl.a. har fokuseret på turtagning, spørgsmålsdesign og narrativer (se fx Atkinson \& Drew 1979; Komter 1994; Harris 2001; Mortensen \& Mortensen 2017).

Retslingvister bliver jævnligt spurgt om de kan afsløre løgne og bedrag ud fra sproglige markører. Det er der meget lidt der tyder på: Forskellige studier finder effekter af markører som personlige pronomener, passiv, negationer og kognitive verber, men der har ikke vist sig nogen markører der holder på tværs af teksttyper og undersøgelsesdesign (se oversigten i Picornell 2013: 21-29). Det bedste bud på at identificere bedrag eller manipulation er at finde inkonsistenser $i$ vidnets eller mistænktes redegørelser, en metode som politiet naturligt nok allerede gør brug af i deres afhøringer.

Blandt de nyere problemstillinger er dem der knytter sig til internetkommunikation og sociale medier. Profilering vil fx kunne bringes $i$ anvendelse i efterforskning af sager mod pædofile der prøver at lokke børn til sig på nettet ved at udgive sig for selv at være børn. Ophavsanalyser vil være relevante i sager om identitetstyveri hvor en person gerne vil bevise at det ikke er hende eller ham der har skrevet bestemte indlxg på nettet. Mere dybdegående interaktionsanalyser vil kunne afklare nogle af faresignalerne i sager om direktørsvindel ved at fokusere på hvilke sproglige strategier svindlerne benytter sig af i såvel telefonopkald som e-mail til virksomheder for at narre dem til at udlevere fortrolig information om password og lignende, og sidenhed presse betroede medarbejdere til at overføre store summer i påståede hastesager (jf. Tabron 2016) ${ }^{23}$.

23 Se fx http://www.idag.dk/article/view/262362/flere_virksomheder_udsaettes_for_direktorsvindel, 
En stor og væsentlig del af den menneskelige kommunikation foregår med sproget - også den der måske, måske ikke har at gøre med lovovertrædelser. For så vidt som sproglige spor bliver bevaret på en måde så de kan underkastes nærmere undersøgelser, bør retssystemet trække på den ekspertviden som sprogforskere har. Og sprogforskere bør på den anden side bidrage med deres indsigt og vejledning til at beskytte minoriteter og ofre for overgreb i tilfælde hvor den sproglige repræsentation af deres sager tydeligt vil påvirke udfaldet.

\section{Tanya Karoli Christensen}

Institut for Nordiske Studier og Sprogvidenskab

Københavns Universitet

tkaroli@hum.ku.dk

http:/ / nyheder.tv2.dk/krimi/2016-04-14-ny-direktoersvindel-rammer-danmark-saadanundgaar-du-at-blive-snydt og

http://www.business.dk/okonomi/ivaerksaetteren-martin-thorborg-udsat-for-forsog-padirektorsvindel. 


\section{BILAG 1. TEKST 12}

\section{Hej med dig din gamle predofle stodder!}

O) hare ondt af dig da dit live efter 1. februar vil xendre sig totalt hwis du ikhe betaler hwad du skylder.

Sxely din baid og fa den gamle vilbage............... sai hav du vid.....

O) Tover dig wi averhalder hwad wi har lovet dig......... og ingen eller intet kan sendre dette du er et suin som har snydt sai mange samt den hone du var gift med $i$ suger da du ikke kunne holde dine beskidte fingre fra hendes datter.

QDin omverden vilf fa alt i vide om dig men du har fortsat et valy som du ved ag som vi meget kraftigt steal vaide dig til at welge vigtigt alt andet vil were lidt synd og undholdeligt for dig vi ved jo du ev en tosedveng de andre siger du allerede har tudet.....

Sou gadt i dit flatte sort betalte rekkehus sai lange det warer hwis du ikke........... 


\section{LITTERATUR}

Atkinson, J.M. \& P. Drew. 1979. Order in court: The organisation of verbal interaction in judicial settings. London: Macmillan. DOI: 10.1007/978-1-349-04057-5.

Berk-Seligson, S. 1999. The impact of court interpreting on the coerciveness of leading questions. Forensic Linguistics 6. 30-56. DOI: 10.1558/sll.1999.6.1.30.

Berk-Seligson, S. 2002. The miranda warnings and linguistic coercion: The role of footing in the interrogation of a limited-english-speaking murder suspect. J. Cotterill (red.). Language in the legal process, 127-143. London: Palgrave Macmillan UK.

Brøndum-Nielsen, J. 1914. Sproglig forfatterbestemmelse: Studier over dansk sprog $i$ det 16. Århundredes begyndelse. København: Gyldendal.

Butters, R.R. 2012. Retiring president's closing address: Ethics, best practices, and standards. Proceedings of the International Association of Forensic linguists' tenth biennial conference 10. 351-361.

Chaski, C.E. 2001. Empirical evaluations of language-based author identification techniques. Forensic linguistics 8. 1-65. DOI: 10.1558/sll.2001.8.1.1.

Chaski, C.E. 2007. The keyboard dilemma and authorship identification. Advances in digital forensics III 242. 133-146. DOI: 10.1007/978-0-387-73742-3_9.

Cotterill, J. 2000. Reading the rights: A cautionary tale of comprehension and comprehensibility. Forensic linguistics 7(1). 4-25. DOI: 10.1558/sll.2000.7.1.4.

Coulthard, M. 2000. Whose text is it? On the linguistic investigation of authorship. S. Sarangi \& M. Coulthard (red.). Discourse and social life, 270-287. London: Longman.

Coulthard, M. 2002. Whose voice is it? Invented and concealed dialogue in written records of verbal evidence produced by the police. J. Cotterill (red.). Language in the legal process, 19-34, Palgrave Macmillan.

Coulthard, M. 2004. Author identification, idiolect, and linguistic uniqueness. Applied linguistics 25(4). 431-447. DOI: 10.1093/applin/25.4.431.

Coulthard, M., A. Johnson \& D. Wright. 2017. An introduction to forensic linguistics: Language in evidence. London: Routledge.

Eades, D. 2005. Applied linguistics and language analysis in asylum seeker cases. Applied linguistics 26(4). 503-526. DOI: 10.1093/applin/ami021.

Ehrhardt, S. 2013. Forensic linguistics accredited: Four years of experiences with ISO 17020 in authorship analysis. Bridging the gap(s) between language and the law: Proceedings of the 3rd European conference of the International Association of Forensic Linguists. Porto, Portugal. Faculdade de Letras da Universidade do Porto. 64-75. 
Ehrhardt, S. 2016. Forensic linguistics at the German Bundeskriminalamt. Foredrag ved IV Jornadas de Lingüistica Forense, Madrid.

Farstad Eriksen, P.K. 2013. Avhørsrapporten som rekontekstualisering av avhøret. En studie av en simulert avhørssituasjon gjennomført av studenter ved politihøgskolen. Institutt for språk- og kommunikasjonsstudie. Trondheim: NTNU. MA.

Fisher, S.Z. 1993. Just the facts, ma'am: Lying and the omission of exculpatory evidence in police reports. New England law review 28(1). 1-62.

Fraser, B. 1998. Threatening revisited. Forensic linguistics 5. 159-173. DOI: 10.1558/ sll.1998.5.2.159.

Gnisci, A. \& C. Pontecorvo. 2004. The organization of questions and answers in the thematic phases of hostile examination: Turn-by-turn manipulation of meaning. Journal of pragmatics 36(5). 965-995. DOI: 10.1016/j.pragma.2003.10.005.

Grant, T. 2012. Txt 4n6: Method, consistency, and distinctiveness in the analysis of sms text messages. Journal of law and policy 21(2). 467-494.

Grice, H.P. 1975. Logic and conversation. P. Cole \& J.L. Morgen (red.). Syntax and semantics 3: Speech acts, 41-58. New York: Academic.

Harris, S. 2001. Fragmented narratives and multiple tellers: Witness and defendant accounts in trials. Discourse studies 3(1). 53-74. DOI:10.1177/1461445601003001003.

Haworth, K. 2006. The dynamics of power and resistance in police interview discourse. Discourse \& Society 17(6). 739-759. DOI: 10.1177/0957926506068430.

Heltoft, L. \& E. Hansen. 2011. Grammatik over det danske sprog. København: Det Danske Sprog- og Litteraturselskab.

Holmes, D. I. 1998. The evolution of stylometry in humanities scholarship. Literary and linguistic computing 13(3). 111-117. DOI: 10.1093/llc/13.3.111.

Jarvad, P. 2014. Juridisk sprog. Sporg om sprog. 40 år i Dansk Sprognavn. 43-59. København, Dansk Sprognævn.

Jessen, M. 2008. Forensic phonetics. Language and linguistics compass 2. 671-711. DOI: 10.1111/j.1749-818X.2008.00066.x.

Julien, M. 2016. Possessive predicational vocatives in scandinavian. The journal of comparative Germanic linguistics 19(2). 75-108. DOI: 10.1007/s10828-016-9081-x.

Juola, P. 2008. Authorship attribution. Foundations and trends in information Rrtrieval 1(3). 233-334. DOI: 10.1561/1500000005.

Juola, P. 2016. Did aunt Prunella really write that will? A simple and understandable computational assessment of authorial likelihood. Proceedings of $A$ workshop on legal text, document, and corpus analytics (LTDCA 2016). 37-41. 
Jönsson, L. \& P. Linell. 1991. Story generations: From dialogical interviews to written reports in police interrogations. Text - Interdisciplinary journal for the study of discourse 11(3). 419-440. DOI: 10.1515/text.1.1991.11.3.419.

Kassin, L. 2008. Confession evidence: Commonsense myths and misconceptions. Criminaljustice and behavior35(10).1309-1322. DOI:10.1177/0093854808321557.

Komter, M.L. 1994. Accusations and defences in courtroom interaction. Discourse \& society 5(2). 165-187. DOI: 10.1177/0957926594005002002.

Koppel, M., J. Schler \& S. Argamon. 2009. Computational methods in authorship attribution. Journal of the American Society for Information Science and Technology 60(1). 9-26. DOI: 10.1002/asi.20961.

Københavns Kommune. 1991. Kan "staveplade" anvendes som kommunikationsmiddel for egne, viljesbestemte udsagn? En undersogelse af stavepladekommunikation mellem klienter med vidtgaiende psykisk og eventuelt fysisk handicap og deres padagoger. København: Københavns Amt.

Larsen, P.H. 1973. Om "offentligt at tilskynde til forbrydelse". En studie i forholdet mellem sprog, jura og politik. Nydanske sprogstudier 5. 5-39. DOI: 10.7146/nys. v5i5.10339.

Leonard, R.A., J.E.R. Ford \& T.K. Christensen. 2017. Forensic linguistics: Applying the science of linguistics to issues of the law. Hofstra Law Review 45. 501-517.

Love, H. 2002. Attributing authorship: An introduction. Cambridge: Cambridge University Press.

McMenamin, G.R. 2002. Forensic linguistics: Advances in forensic stylistics. New York: CRC Press. DOI: 10.1201/9781420041170.

Mortensen S. S. \& J. Mortensen. 2017. Epistemic stance in courtroom interaction. F. Poggi, A. Capone (red.), Pragmatics and law. Perspectives in pragmatics, philosophy \& psychology 10. Cham: Springer, 401-437. DOI: 10.1007/978-3-319-44601-1_16.

Nakane, I. 2011. The role of silence in interpreted police interviews. Journal of pragmatics 43(9). 2317-2330. DOI: 10.1016/j.pragma.2010.11.013.

Olsson, J. \& J. Luchjenbroers. 2014. Forensic linguistics: London: Bloomsbury Academic Press.

Patrick, P.L. 2012. Language analysis for determination of origin: Objective evidence for refugee status determination. M.S. Lawrence, M.T. Peter \& L.P. Peter (red.), The Oxford handbook of language and law, 1-15. Oxford: Oxford University Press.

Picornell, I. 2013. Cues to deception in a textual narrative context: Lying in written witness statements. Ph.d.-afhandling ved School for Languages and Social Sciences. Aston: Aston University. 
Schack, J. 2008. Varemærker i den sproglige rådgivning. Sprog $i$ Norden 39(1). 223-229.

Searle, J.R. 1969. Speech acts: An essay in the philosophy of language. Cambridge: Cambridge University Press. DOI: 10.1017/CBO9781139173438.

Shuy, R.W. 2006. Linguistics in the courtroom: A practical guide. Oxford: Oxford University Press.

Shuy, R.W. 2008. Fighting over words: Language and civil law cases. Oxford: Oxford University Press. DOI: 10.1093/acprof:oso/9780195328837.001.0001.

Shuy, R.W. 2013. The language of bribery cases. Oxford: Oxford University Press. DOI: 10.1093/acprof:oso/9780199945139.001.0001.

Shuy, R.W. 2015. Discourse analysis in the legal context. D. Schiffrin, D. Tannen \& H.E. Hamilton (red.), The handbook of discourse analysis, 822-840. Hoboken: WileyBlackwell.

Shuy, R.W. 2017. Language and Law. M. Aronoff \& J. Rees-Miller (red.), The handbook of linguistics, 627-641. Hoboken: Wiley-Blackwell.

Simons, A. \& R. Tunkel. 2013. The assessment of anonymous threatening communications. J.R. Meloy \& J. Hoffmann (red.), International handbook of threat assessment, 195-213. Oxford: Oxford University Press.

Solan, L.M. \& P.M. Tiersma. 2010. Speaking of crime: The language of criminal justice. Chicago: University of Chicago Press.

Solan, L.M. 2013. Intuition versus algorithm: The case of forensic authorship attribution. Brooklyn journal of law and policy 21(2). 551-576.

Svartvik, J. 1968. The Evans statements: A case for forensic linguistics. Gothenburg: University of Gothenburg.

Tabron, J. 2016. Linguistic features of phone scams: A qualitative survey. Foredrag ved 11th Annual Symposium on Information Assurance (ASIA '16), Albany, New York.

Tagliamonte, S. 2011. Variationist sociolinguistics: Change, observation, interpretation. West Sussex: John Wiley \& Sons.

Togeby, O. 1993. Praxt. Pragmatisk tekstteori. Aarhus: Aarhus Universitetsforlag.

Verrips, M. 2011. LADO and the pressure to draw strong conclusions. International journal of speech, language \& the law 18(1). 131-143. DOI: 10.1558/ijsll.v1811.131.

Walton, D. 2013. Scare tactics: Arguments that appeal to fear and threats. Dordrecht: Kluwer Academic Publishers. 